\title{
Trans-SEC's food security research in Tanzania: from constraints to adoption for out- and upscaling of agricultural innovations
}

\author{
Stefan Sieber ${ }^{1} \cdot$ Frieder Graef $^{1} \cdot$ T. S. Amjath-Babu ${ }^{1} \cdot$ Khamaldin Daud Mutabazi $^{2} \cdot$ Siza D. Tumbo $^{2} \cdot$ Anja Faße $^{3}$. \\ Sergio Gomez y Paloma ${ }^{4}$. Constance Rybak ${ }^{1}$ - Marcos Alberto Lana ${ }^{1,5} \cdot$ Hycenth Tim Ndah $^{1} \cdot$ Götz Uckert $^{1}$. \\ Johannes Schuler ${ }^{1}$ • Ulrike Grote ${ }^{6}$
}

Received: 7 May 2018 / Accepted: 26 June 2018 / Published online: 2 August 2018

(C) Springer Nature B.V. and International Society for Plant Pathology 2018

\section{Introduction}

Implementing agricultural innovations is key for coping strategies in the contexts of climate change and food security (Senyolo et al. 2018; Bommarco et al. 2018). The agricultural sector is still the central focus for rural development, especially in remote areas of Sub-Saharan Africa. Links to Small and Medium-size Enterprises (SMEs), among others, are often lacking, due to comparatively high costs for logistics, transport, and communication (Letiche 2010; Meyfroidt 2018; Stephens et al. 2018). Peri-urban and rural areas need specific and tailored livelihood strategies (Fraval et al. 2018). Thus, enabling environments for business models and alternative ecosystem services (Bommarco et al. 2018) are difficult to establish. Low economies of size and scale hinder the establishment of profitable economies (Tomich et al. 2018; Letiche 2010). Nevertheless, manifold implementation models for upgrading agricultural activities do exist and are continuously being tested and adapted in international research projects

Stefan Sieber

stefan.sieber@zalf.de

1 SusLAND Sustainable Land Use in Developing Countries, Farm Economics and Ecosystem Services, Leibniz Centre for Agricultural Landscape Research (ZALF), Müncheberg, Germany

2 Agricultural Economics and Agribusiness, Sokoine University of Agriculture, Morogoro, Tanzania

3 University of Applied Sciences Weihenstephan-Triesdorf (HSWT), Straubing, Germany

4 Institute for Prospective Technological Studies (IPTS), European Commission, Joint Research Centre (JRC), Seville, Spain

5 Department of Crop Production Ecology, Swedish University of Agricultural Sciences, Ulls väg 16, Uppsala 750 07, Sweden

6 Institute for Environmental Economics and World Trade, Leibniz University, Hannover, Germany
(Candel 2017). Specific implementation models disseminate innovations despite various structural problems of research and development in Sub-Saharan Africa (Lipton 1988).

Among these theoretical models, the main challenge remaining is how agricultural innovations can be disseminated efficiently and effectively through outscaling and upscaling, given varying site conditions and diverse target groups (Senyolo et al. 2018). While pro-poor approaches focus mostly on small-scale farmers, the question of the right setting for agricultural innovations persists. In less favorable areas, typically low-cost innovations are more suitable due to limited capacities (capital), while higher income farmers in favorable production areas might seek higher investments and more revenue through market integration (Tomich et al. 2018). Additionally, at local levels, some farmers are more innovative than others, seeking different agro-ecological transformation strategies (Tittonell 2014). These superior performing farmers are more likely to adopt new techniques, even if they are riskier (Steinke and van Etten 2018). Innovators and catalyzers are key to more efficient and reliable adoption of agricultural innovations (Steinke and van Etten 2018; Below et al. 2015; Uckert et al. 2015). The issue of innovation adoption is an important research topic bridging the gap between "maximum yield potential" and actual yields harvested in farmers' fields (Foley et al. 2011). Such research should be long term and monitored over time in order to arrive at sustainable improvements. Agricultural innovations should be continually optimized in response to changing conditions (Tomich et al. 2018; Mutabazi et al. 2015, Senyolo et al. 2018, Below et al. 2015). Furthermore, an adequate incentive structure is a necessity for the long-term adoption of successful techniques (Nhantumbo et al. 2016).

These applied adoption theories are closely linked and indispensably coupled with out- and upscaling methods, which seek efficient and effective horizontal and vertical 
dissemination of innovations. While horizontal out-scaling is the dissemination from farmer-to-farmer or means-to-farmerapproaches (i.e. radio, field exhibitions, leaflets, farmer field schools, or extension), the vertical way uses efficiencies through upscaling via policy or education programs. These have the highest dissemination rates with the lowest inputs (i.e. regulations/laws, curricula, education programs). Hence, out- and upscaling activities are key for effecting innovative agriculture. Good examples include, first, bio-fortification through introducing new seeds with high vitamin content and, second, low-cost irrigation systems to overcome water scarcity (Laurie et al. 2015, 2018). Household or individual levels of access to food, dietary quality, and nutritional impacts within these systems are often underrepresented in research (Stephens et al. 2018). Hence, linking food security and nutrition-sensitive agriculture is an important research activity. One outcome should be the mitigation of stunting.

In the first part of this special section (Sieber et al. 2017) the large research project Trans-SEC was outlined as having the following methodological components: (1) the Trans-SEC conceptual framework (TCF); (2) the basic research principles for inter- and trans-disciplinary research; (3) the upgrading strategies (UPS) as agricultural innovations; as well as (4) the Trans-SEC research model (TRM). The overall TransSEC goal is to test innovations in order to improve the food security situation at the community level. In this regard the question remains whether the innovations can be disseminated effectively, such that small-scale farmers can cost-efficiently adopt these new practices.

These considerations asked for an adequate out- and upscaling dissemination strategy. Hence, each innovation had to be tailored to the specific site conditions of the implementing region. This challenge of developing an adequate method for local characteristics is a tightrope walk: on the one hand, there is the goal to (1) maximize generalizability and reproducibility of food security strategies, considering guiding principles for applying innovations and, on the other hand, each implementing method needs (2) to be specific enough to tailor agricultural innovations to site-specific conditions and target groups. In this regard, the Trans-SEC project part II reported here targets the conceptualization of the general Trans-SEC food and nutrition security model. It specifically analyses potentials for out- and upscaling of respective agricultural innovations with regard to:

- Constraints preventing the efficient and effective dissemination of agricultural innovations (so called upgrading strategies (UPS)) - these constraints lead to mal-adoption;

- Description of the Food and Nutrition Security Model (FNSM) for interventions to build development options for small-scale farmers; and

- The UPS-specific out- and upscaling levels that are known to build dissemination strategies.

\section{Implementation constraints, system complexity and scalability}

In order to explain the general findings of Trans-SEC, we systemize system-immanent problems and, from there, derive solution-based strategies. In this regard the three steps from constraints (see Section 2.1) toward system-analysis using the model FNSM (see Section 2.2), up to levels for effective outand upscaling (see Section 2.3) are illustrated in the following with examples of agricultural innovations.

\subsection{Implementation constraints for agricultural innovations}

Successful interventions are complex to implement and, thus, need to be considered in an agricultural system approach (Graef et al. 2014, 2015). The bottlenecks must be carefully discussed in order to overcome the related challenges. In this regard, Fig. 1 illustrates the constraints of agricultural innovations (UPS) along Food Value Chain components (FVC), which are generally not visible before implementation. In summary, these bottlenecks are either the high labour input for short implementation periods (ridging, weeding, see 1a Fig. 1) or, if investments are needed (costs for oxen, ridging tool, cost sharing of fertilizer, see $1 \mathrm{~b}-$ Fig. 1), the complex underlying social organisation, including business models and cooperative systems. Liquidity for financial input is often lacking and, therefore, needs business models among involved farmers. The formation of a business group for making economic investments is key for success (business groups, see $6,7,8$ or 1 b - Fig. 1). The motivations, incentive structure, and composition of the group, as well as power relations related to opinion holders, innovators, and excluded farmers must be carefully and simultaneously considered. In many cases, market-related technical hurdles, such as the availability of only large-sized fertilizer bags, cannot be easily overcome without political pressure: convincing market participants to provide smaller, more affordable, units of fertilizer will help poor farmers afford to use them (see 1b, Fig. 1). Moreover, the logistics and infrastructure of market systems often need high investments or low-cost decentralized solutions. Both need long-term planning and often are only realizable at the small-scale level. Soft skills, such as technical aptitude of innovators, and characteristics of actors, including high intrinsic motivation, endurance, and cleverness, are sometimes unpredictable or not easy to identify (see 7 - Fig. 1). Across all UPS, one important factor is 'knowledge' through education and training measures (see 8 - Fig. 1). All these constraints determine the 'enabling environment' of agricultural innovations for UPS.

We found two major types of interventions, which can be defined as (a) coping strategies in enabling environments with high pressure on scarce favourable conditions such as water 


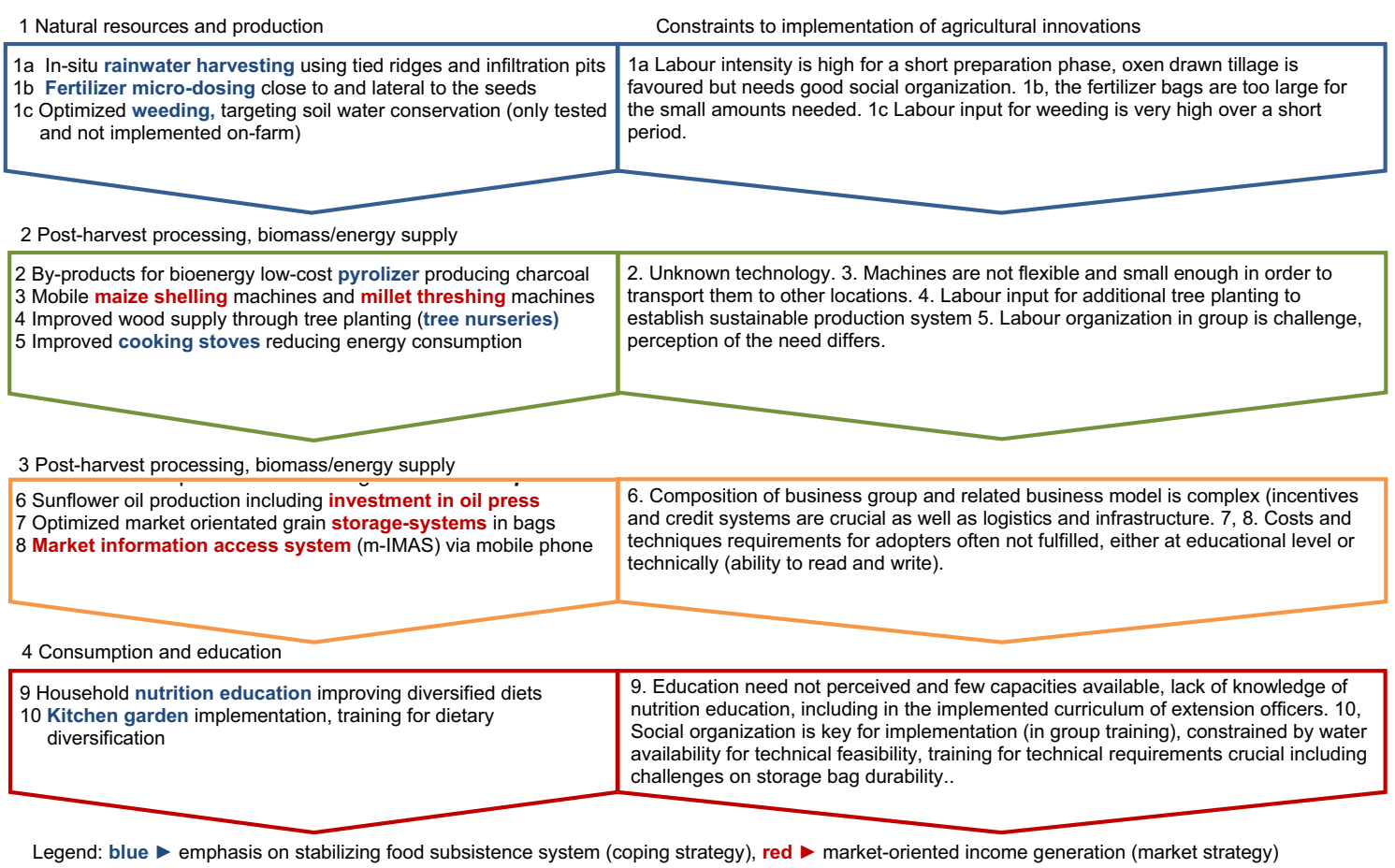

Fig. 1 The tested agricultural innovations as upgrading-strategies (UPS) along the Food Value Chain (FVC) and implementation constraints

and good soil quality; and (b) linking to markets to upgrade subsistence farming systems by generating additional income from markets and by stabilizing livelihoods though division of labour. These two types of interventions are illustrated in Fig. 1 (see legend), which differ in (a) stabilizing farm systems without direct market linkage (coping strategy) shown in UPS numbers $1,2,4,5,8$, and 9, while (b) the remaining ones, 3 , 6 , and 7 , are for income generation seeking (market strategies).

All interventions described in Fig. 1 are not singular, but rather complex, interlinked, and system-relevant. This means that integrated approaches are needed not just for the simultaneous consideration of the implementation processes of innovations, but also the related constraints. These constraints limit the available implementation capacities of the stakeholders involved, such as farmers and extension officers (Sieber et al. 2015a, b). Due to this high complexity, careful prioritysetting in financially scarce environments is needed. This maximization of impacts and simultaneous costminimization is one of the greatest challenges for implementing organizations (Akullo et al. 2018). Therefore, detailed knowledge of the system complexity and its specific challenges is key. Finding site-explicit tailored implementation models for research, such as the exemplified FNSM in Fig. 2, is a challenge.

\subsection{Trans-SEC's food and nutrition security model (FNSM)}

The integrated and generic Trans-SEC - Food and Nutrition Security Model (FNSM) (see Fig. 2) was developed specifically to classify Trans-SEC's agricultural innovations (Sieber et al. 2017).

Trans-SEC implemented a bundle of interventions that was selected and developed through participative involvements by stakeholders, mostly small-scale farmers. The assumption is that this tacit-knowledge within the community (social capital) is the best proxy for the actual implementation needs. In this case, the stakeholders themselves select the agricultural innovations to be implemented. The possible up-grading steps of farmers are achieved by following the pathway described in Fig. 2:

The FNSM in Fig. 2 classifies the innovations into (A) coping activities; (B) small scale business in agriculture; (C) seeking opportunities for income generation; and (D) downand upstream business with/without agricultural integration (SMEs). From the short and mid-term perspective, no sustainable solutions are possible. Food aid is a short-term solution. From the mid-term perspective, implemented innovations can be tested and, if successful, implemented for long-term use.

Against this background, these are the following general pathways: (A) fostering coping strategies to stabilize poor livelihoods and food insecure situations; (B) starting off from a more stable situation and establishing a small-scale business with slightly increased inputs. Once the food and nutrition situation are stabilized or the situation is per se secure, further economic development can be achieved through (C) increasing inputs (land, labour, capital) to establish market integration and also connect FVC components across different sectors; or (D) generate income in other sectors such as tourism, energy, and agriculture-related services such as consulting and 
Fig. 2 Food and Nutrition Security Model (FNSM)

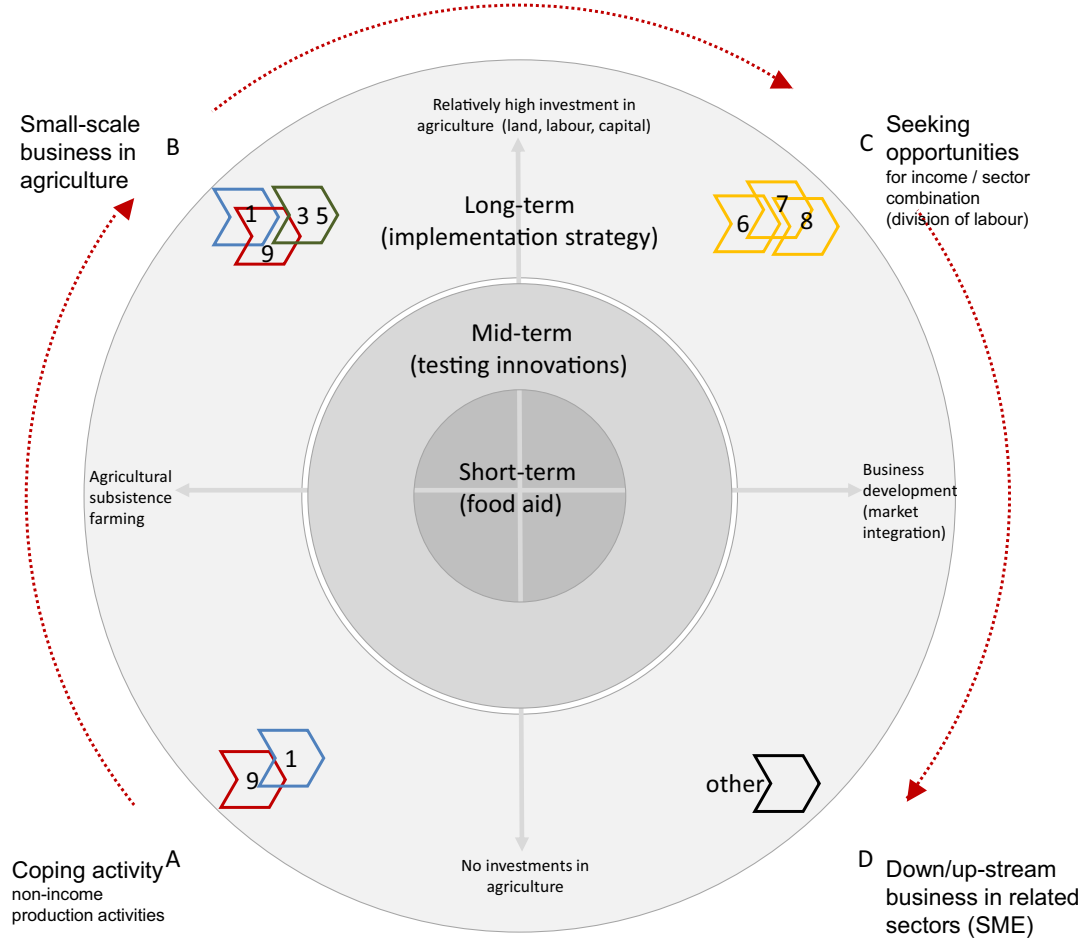

Legend:

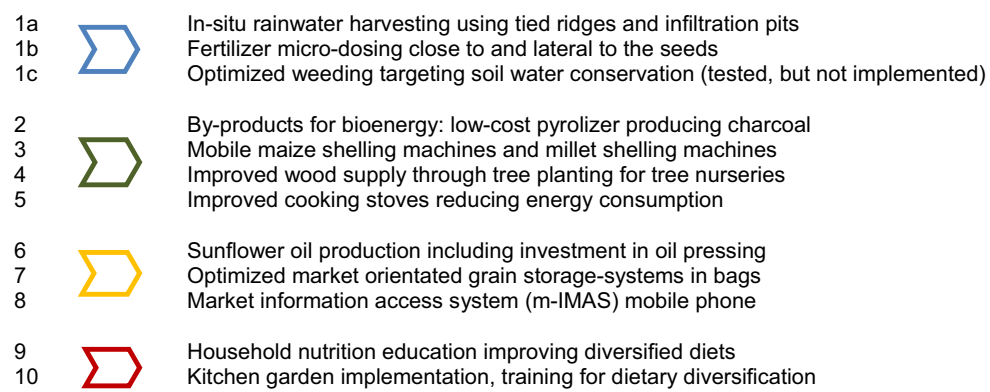

trading. Exclusive business outside the agricultural sector as alternative income source (e.g. credits, insurances, and infrastructure) is favourable if labour can be utilized more efficiently.

The dynamics within the FNSM are driven by the actors involved, who identify and commence the pathway from A to $\mathrm{B}$ and, eventually, $\mathrm{C}$ and D of how food and nutrition securing strategies are set up and applied. Generally, a consensus among decision makers and additional stakeholders is key for success; however, sometimes a single innovator, as a positive deviant, may achieve a similar or even better positive result. Free riders and strategic behaviour by opinion holders hinder positive impacts within the communal society. Thus, the question on the adequate implementation model of how agricultural innovations can be implemented in a sustainable setting arises. Here, Trans-SEC tested only one implementation model out of a wide range of possible variations of models (inter alia Graef et al. 2014, Tittonell et al. 2012, Schut et al. 2015, Notenbaert et al. 2017), each with different components and implementation procedures. A promising method is positive deviance (Steinke and van Etten 2018), which first contacts innovators to establish a small upscaling centre at community level. An adequate enabling environment for any intervention on agricultural innovations is also important. The major challenge is to overcome the constraints within the agricultural system that hinder stakeholders from properly implementing changes. Based on our research, reasons for this (see Fig. 1) are ranked in order of importance: (1) the opportunity costs of labour; (2) social organization of farmer implementation groups; (3) access to credit; (4) technological, process-oriented knowledge; and (5) cultural, traditional reasons and gender. The ranking changes depending on the individual type of agricultural innovation; therefore it is only generally representative across all tested innovations. 


\subsection{Levels for effective out- and upscaling}

Out- and upscaling of successfully tested agricultural innovations need a tailored concept for dissemination. The characteristics of this concept depend on site conditions as well as the specifics of the target group. Twofold dissemination procedures are possible: (1) Up-scaling is most efficient since, through implementation of findings with policy programmes in other regions, target groups can be easily addressed, presuming that actual policies are effective. (2) Out-scaling, involving farmer-to-farmer outreach for knowledge transfer, either to other regions or simply to other target groups within the same region, is equally important as a complementary dissemination measure. Based on interviews within the Trans-SEC consortium, the following levels were identified for dissemination of agricultural innovations. They relate mostly to upscaling activities, although (3) and (4) can also involve outand upscaling activities simultaneously (see Fig. 3).

Legislation: Generally, it is favourable that simple regulatory measures, which are easy to communicate and implement, are transferred through laws and regulations. Inter alia, energy-efficient cooking stoves, which are relatively simple to construct, are ideal to implement via national or regional regulations. Especially helpful are all easy to implement innovations that are simple in construction, design, or guiding principles (e.g. educational objectives).

Curriculum within public authorities: All findings that are "standardisable" as educational tools or components within curriculum are adequate; either through excursion or practical training components as well as in university / school teaching programs. This measure is as efficient as legislation, but targets the students who, subsequently, are the "experts" and, thus, promoters of the specifics.

National action plans: e.g. the National Adaptation Programme of Action (NAPA) targets specific thematic areas, defining adaptation measures and relationships with development goals. These fields of actions outline country-specific programs to tackle identified challenges with regard to climate change, food security, and related risks. New findings in innovation research, such as guiding principles, can be regionexplicitly involved in the NAPAs.

District level-specific actions plans: these plans are more detailed and represented through local government agencies at the district level, which tailor programs to site-conditions. Specific technology and promoter programs can be applied, although they are generally the same as in (3).

\begin{tabular}{|c|c|c|c|c|c|}
\hline $\begin{array}{l}\text { 1. Legislation } \\
\text { at higher } \\
\text { internationa } \\
\text { I or national } \\
\text { level }\end{array}$ & $\begin{array}{l}\text { Legislation to overcome } \\
\text { technical constraints (e.g. } \\
\text { fertilizer bag size at } \\
\text { distributors), cooperative } \\
\text { enhancement for ridging tools }\end{array}$ & $\begin{array}{l}\text { Legislation to construct } \\
\text { efficient stoves, tools } \\
\text { within defined period } \\
\text { and eventual support } \\
\text { through micro-credits }\end{array}$ & $\begin{array}{l}\text { Legislation for } \\
\text { compulsory learning on } \\
\text { tools, machines, devices } \\
\text { to be able to store at } \\
\text { communities }\end{array}$ & $\begin{array}{l}\text { Legislation for } \\
\text { compulsory learning at } \\
\text { community schools on } \\
\text { nutrition and school } \\
\text { gardens }\end{array}$ & \multirow{6}{*}{$\begin{array}{l}\text { 1a In-situ rainwater harvesting using tied } \\
\text { ridges and infiltration pits } \\
1 \text { b Fertilizer micro-dosing close to and } \\
\text { lateral to the seeds } \\
\text { 1c Optimized weeding targeting soil water } \\
\text { conservation } \\
2 \text { By-products for bioenergy low-cost } \\
\text { pyrolizer producing charcoal } \\
3 \text { Mobile maize shelling machines and } \\
\text { millet shelling machines } \\
4 \text { Improved wood supply through tree } \\
\text { planting for tree nurseries } \\
\text { D } \\
5 \text { Improved cooking stoves reducing energy } \\
\text { consumption } \\
6 \text { Sunflower oil production including } \\
\text { investment in oil pressing } \\
7 \text { Optimized market orientated grain } \\
\text { storage-systems in bags } \\
8 \text { Market information access system (m- } \\
\text { IMAS) mobile phone } \\
\sum \text { E } \\
9 \text { Household nutrition education improving } \\
\text { diversified diets } \\
10 \text { Kitchen garden implementation, } \\
\text { training for dietary diversification }\end{array}$} \\
\hline $\begin{array}{l}\text { 2. National } \\
\text { Curriculum } \\
\text { at university } \\
\text { and } \\
\text { secondary } \\
\text { school } \\
\text { levels } \\
\end{array}$ & $\begin{array}{l}\text { Dissemination of good } \\
\text { practice in curriculum at } \\
\text { university level and national } \\
\text { farmer school concepts }\end{array}$ & $\begin{array}{l}\text { Construction plan on } \\
\text { technology of stoves, } \\
\text { tools and related } \\
\text { processes at University } \\
\text { for Agriculture }\end{array}$ & $\begin{array}{l}\text { Storage technology, } \\
\text { mobile machines (e.g. } \\
\text { milling) as technology in } \\
\text { technical universities }\end{array}$ & $\begin{array}{l}\text { Crosscutting university } \\
\text { curriculum for } \\
\text { nutritionists, nurses, } \\
\text { medical and sanitary } \\
\text { professions }\end{array}$ & \\
\hline $\begin{array}{l}\text { 3. National } \\
\text { standardise } \\
\text { d action } \\
\text { plan of } \\
\text { innovations } \\
\end{array}$ & $\begin{array}{l}\text { General guiding principles for } \\
\text { micro-dosing and tied-ridges } \\
\text { if applied at local sites }\end{array}$ & $\begin{array}{l}\text { General guiding } \\
\text { principles on the } \\
\text { construction of } \\
\text { respective stoves, } \\
\text { processing of tools } \\
\end{array}$ & $\begin{array}{l}\text { General guiding } \\
\text { principles on the use of } \\
\text { machines, tools and } \\
\text { devices including } \\
\text { instructions }\end{array}$ & $\begin{array}{l}\text { Kitchen garden concept } \\
\text { through school gardens } \\
\text { systems disseminated at } \\
\text { community level }\end{array}$ & \\
\hline $\begin{array}{l}\text { 4. Sub- } \\
\text { national } \\
\text { guiding } \\
\text { action plan } \\
\text { at district } \\
\text { level } \\
\end{array}$ & $\begin{array}{l}\text { Specific innovation bulking } \\
\text { (fertilizer, ridges, ties, } \\
\text { weeding) in combination as } \\
\text { tailored to local government } \\
\text { agencies (LGAs) - program }\end{array}$ & $\begin{array}{l}\text { Specific dissemination } \\
\text { promoter program } \\
\text { with bonus for } \\
\text { implementation to } \\
\text { implement stoves, } \\
\text { tools }\end{array}$ & $\begin{array}{l}\text { Specific delivery services } \\
\text { at the level of PICS- } \\
\text { bags bulking for low- } \\
\text { costs purchase, other } \\
\text { tools }\end{array}$ & $\begin{array}{l}\text { District level specifics to } \\
\text { be defined in promoter } \\
\text { programs, regional } \\
\text { education, kitchen } \\
\text { gardens }\end{array}$ & \\
\hline $\begin{array}{l}\text { 5. Sub-district } \\
\text { - local } \\
\text { farmer to } \\
\text { farmer } \\
\text { approach }\end{array}$ & $\begin{array}{l}\text { Exhibitions, demonstration } \\
\text { sites for successful examples } \\
\text { through hands-on-learning. } \\
\text { Specific methods such as } \\
\text { community radio }\end{array}$ & $\begin{array}{l}\text { Associations, NGOs } \\
\text { disseminate the } \\
\text { information via media } \\
\text { (school, training, radio, } \\
\text { assembly, leaflets) }\end{array}$ & $\begin{array}{l}\text { Associations, NGOs } \\
\text { disseminate the } \\
\text { information via media } \\
\text { (school, training, radio, } \\
\text { assembly, leaflets) }\end{array}$ & $\begin{array}{l}\text { Concept of school } \\
\text { garden dissemination } \\
\text { through famer or } \\
\text { primary schools, other } \\
\text { media, teachers }\end{array}$ & \\
\hline $\begin{array}{l}\text { 6. } \\
\text { recal - } \\
\text { region } \\
\text { explicit } \\
\text { agricultural } \\
\text { innovation }\end{array}$ & $\begin{array}{l}\text { Tailored concepts through } \\
\text { extension officers, farmer } \\
\text { schools and community } \\
\text { representatives to implement } \\
\text { innovations }\end{array}$ & $\begin{array}{l}\text { Extension officer, } \\
\text { villages promoter to be } \\
\text { trained by LGAs to } \\
\text { tailor the community } \\
\text { programs, schools }\end{array}$ & $\begin{array}{l}\text { Extension officer, village } \\
\text { promoter to be trained } \\
\text { via LGAs to tailor the } \\
\text { community programs, } \\
\text { schools }\end{array}$ & $\begin{array}{l}\text { Specific teacher program } \\
\text { at schools, extension } \\
\text { officer at farmer schools, } \\
\text { children teaching } \\
\text { program }\end{array}$ & \\
\hline
\end{tabular}

Fig. 3 Themes and levels of out- and upscaling activities for effective dissemination 
The following levels, 5 and 6 , are identified for the dissemination of agricultural innovations, mostly for out-scaling activities, since region-specific concepts on agricultural innovations can be disseminated via farmer-to-farmer approaches, inter alia. These can be defined as follows (see Fig. 3):

At the sub-district local level, such as the Wared level or, even lower, farmer-to-farmer, the approach comprises dissemination events, including exhibitions, community radio, or local associations that transfer knowledge through leaflets, guides, or workshops. These can also incorporate focus group techniques. Specific local government agencies (LGAs) may be involved and also connected to up-scaling activities in singular cases.

At the local community level, extension officers can tailor community-specific concepts to out-scale and also to up-scale targeted activities, thus bringing them to the community. Via LGAs, extension officers can be trained in collaboration with Small and Medium-sized Enterprises (SMEs). The extension officers can accompany specific implementation processes throughout the outscaling process and require SME's inputs at the request of involved stakeholders.

The last is especially important if agricultural inputs, such as fertilizer, are lacking. Feedback loops involving primary and farmer schools may be applied if they exist at the local level (e.g. school garden concepts). Further, if successful concepts are proven (e.g. kitchen garden concepts), then teaching programs can be disseminated via local authorities from one village to another.

In summary, on the one hand, the exemplified out- and upscaling levels in Trans-SEC show exceptional diversity across all tested innovations for the main characteristics, with the amount of time needed varying drastically. While on the other hand, national changes in legislation or a representative innovation program in NAPAs may need several years of lobbying and tailored policy action strategies from multiple actors. Nevertheless, specific examples of out-scaled agricultural innovations from one target group to another might be relatively easy to guarantee success in a short time. These challenges of out- and upscaling activities for effective dissemination differ across the four illustrated components: (a) country regulations and related sub-scales; (b) policy types; (c) target groups; and (d) supporting organizational settings from governmental (e.g. farmer school), private (e.g. SMEs) and nonpublic (e.g. NGOs) levels (Fig. 3).

\section{Conclusions}

This paper presents (1) the constraints to disseminate efficiently and effectively agricultural innovations; (2) a food and nutrition security model (FNSM) to conduct interventions successfully; and (3) the specific out- and upscaling levels for agricultural innovations (upgrading strategies UPS) as challenges to efficiently develop more detailed dissemination strategies. Social organization within specific business groups and micro credit systems, as well as technical and cultural limitations, are key challenges across all innovations. The FNSM classifies the innovation types applied in Trans-SEC and the pathway of a potential farmer development is described. Classification of the agricultural innovations in FNSM enables better planning and implementation in a sustainable way. This can enhance long-term adoption, including continuous adaptation to changing site / frame conditions over time. Efficient dissemination of successful agricultural innovations through out- and upscaling can be formulated and tailored at institutional, legislation, education and farm levels, from the local through (inter-)national levels. Five levels were identified, along with descriptions of the related challenges across national levels and related sub-scales of regulation sub-systems, policy types, target groups, as well as supporting organizational settings.

\section{References}

Akullo, D., Maat, H., \& Wals, A. E. J. (2018). An institutional diagnostics of agricultural innovation; public-private partnerships and smallholder production in Uganda. NJAS - Wageningen Journal of Life Sciences, 84, 6-12.

Below, T. B., Schmid, J. C., \& Sieber, S. (2015). Farmers' knowledge and perception of climatic risks and options for climate change adaptation: A case study from two Tanzanian villages. Regional Environmental Change, 15(7), 1169-1180.

Bommarco, R., Vico, G., \& Hallin, S. (2018). Exploiting ecosystem services in agriculture for increased food security. Global Food Security, 17, 57-63.

Candel, J.-J. L. (2017). Diagnosing integrated food security strategies. NJAS - Wageningen Journal of Life Sciences, 84, 103-113.

Fact Sheets of Trans-SEC, www.trans-sec.org, retrieved by $2^{\text {nd }}$ of November 2017.

Foley J. A., Ramankutty N., Brauman K.A., Cassidy E.S., Gerber J.S., Johnston M., Mueller N.D., O'Connell C., Ray D.K., West P.C., Balzer C., Bennett E.M., Carpenter S.R., Hill J., Monfreda C., Polasky S., Rockström J., Sheehan J., Siebert S., Tilman D., Zaks D.P.M., 2011. Solutions for a cultivated planet. Nature, 478337 342.

Fraval, S., Hammond, J., Lannerstad, M., Oosting, S. J., \& van Wijk, M. T. (2018). Livelihoods and food security in an urban linked, high potential region of Tanzania: Changes over a three year period. Agricultural Systems, 160, 87-95.

Graef, F., Sieber, S., Mutabazi, K., Asch, F., Biesalski, H. K., Bitegeko, J., Bokelmann, W., Bruentrup, M., Dietrich, O., Elly, N., Fasse, A., Germer, J. U., Grote, U., Herrmann, L., Herrmann, R., Hoffmann, H., Kahimba, F. C., Kaufmann, B., Kersebaum, K.-C., Kilembe, C., 
Kimaro, A., Kinabo, J., König, B., König, H., Lana, M., Levy, C., Lyimo-Macha, J., Makoko, B., Mazoko, G., Mbaga, S. H., Mbogoro, W., Milling, H., Mtambo, K., Mueller, J., Müller, C., Mueller, K., Nkonja, E., Reif, C., Ringler, C., Ruvuga, S., Schaefer, M., Sikira, A., Silayo, V., Stahr, K., Swai, E., Tumbo, S., \& Uckert, G. (2014). Framework for participatory food security research in traditional food value chains. Global Food Security 02/ 2014, 3(1), 8-15 Elsevier.

Graef, F., Schneider, I., Fasse, A., Germer, J. U., Gevorgyan, E., Haule, F., Hoffmann, H., Kahimba, F. C., Kashaga, L., Kissoly, L., Lambert, C., Lana, M., Mahoo, H. F., Makoko, B., Mbaga, S. H., Mmbughu, A., Mkangwa, S., Mrosso, L., Mutabazi, K. D., Mwinuka, L., Ngazi, H., Nkonya, E., Reif, C., Said, S., Schaffert, A., Schäfer, M. P., Schindler, J., Sieber, S., Swamila, M., Welp, H. M., William, L., \& Yustas, Y. M. (2015). Assessment of upgrading strategies to improve regional food systems in Tanzania Food processing, waste management and bioenergy, and income generation. Outlook on AGRICULTURE, 44(3), 179-186. https://doi.org/10.5367/oa.2015. 0209.

Laurie, S., Faber, M., Adebola, P., \& Belete, A. (2015). Biofortification of sweet potato for food and nutrition security in South Africa. Food Research International, 76(Part 4), 962-970.

Laurie, S.-M., Faber, M., \& Claasen, N. (2018). Incorporating orangefleshed sweet potato into the food system as a strategy for improved nutrition: The context of South Africa. Food Research International, $104,77-85$.

Letiche, J. M. (2010). Transforming sub-Saharan Africa. Journal of Policy Modeling, 32(2), 163-175.

Lipton, M. (1988). The place of agricultural research in the development of sub-Saharan Africa. World Development, 16(10), 1231-1257.

Meyfroidt, P. (2018). Trade-offs between environment and livelihoods: Bridging the global land use and food security discussions. Global Food Security, 16, 9-16.

Mutabazi, K. D., Amjath Babu, T. S., \& Sieber, S. (2015). Influence of livelihood resources on adaptive strategies to enhance climatic resilience of farm households in Morogoro, Tanzania: An indicatorbased analysis. Regional Environmental Change, 15(7), 12591268.

Nhantumbo, N.-S., Zivale, C. O., Nhantumbo, I. S., \& Gomes, A. M. (2016). Making agricultural intervention attractive to farmers in Africa through inclusive innovation systems. World Development Perspectives, 4, 19-23.

Notenbaert, A., Pfeifer, C., Silvestri, S., \& Herrero, M. (2017). Targeting, out-scaling and prioritising climate-smart interventions in agricultural systems: Lessons from applying a generic framework to the livestock sector in sub-Saharan Africa. Agricultural Systems, 151, 153-162.

Schut, M., Rodenburg, J., Klerkx, L., Kayeke, J., \& Bastiaans, L. (2015). RAAIS: Rapid appraisal of agricultural innovation systems (part II). Integrated analysis of parasitic weed problems in rice in Tanzania. Agricultural Systems, 132, 12-24.

Senyolo, M. P., Long, T. B., Blok, V., \& Omta, O. (2018). How the characteristics of innovations impact their adoption: An exploration of climate-smart agricultural innovations in South Africa. Journal of Cleaner Production, 172(20), 3825-3840.

Sieber, S., Jha, S., Amjath Babu, T. S., Bringe, F., Crewett, W., Uckert, G., Polreich, S., Ndah, H. T., Graef, F., \& Müller, K. (2015a). Integrated assessment of sustainable agricultural practices to enhance climate resilience in Morogoro, Tanzania. Regional Environmental Change, 15(7), 1281-1292.

Sieber, S., Tscherning, K., Graef, F., Uckert, G., \& Gomez y Paloma, S. (2015b). Food security in the context of climate change and bioenergy production in Tanzania: methods, tools and applications. Regional Environmental Change, 15(7), $1163-1168$.

Sieber, S., Amjath-Babu, T. S., Mutabaz, K. D., Tumbo, S. D., Faße, A., Gomez, Y., Paloma, S., Rybak, C., Lana, M., Ndah, T., Götz, U., Schuler, J., \& Grote, U. (2017). Introduction to a special issue: Regional food and nutritional security in Tanzania - Methods, tools and applications. Food Security, 9, $1143-1145$.

Steinke, J., van Etten, J., 2018. Positive deviance analysis, research gate, January 2018, https://doi.org/10.13140/RG.2.2.20282.29128.

Stephens, E. C., Jones, A. D., \& Parsons, D. (2018). Agricultural systems research and global food security in the 21 st century: An overview and roadmap for future opportunities. Agricultural Systems, 163, 1-6.

Tittonell, P. (2014). Livelihood strategies, resilience and transformability in African agroecosystems. Agricultural Systems, 126, 3-14.

Tittonell, P., Scopel, E., Andrieu, A., Posthumus, H., \& Mkomwa, S. (2012). Agroecology-based aggradation-conservation agriculture (ABACO): Targeting innovations to combat soil degradation and food insecurity in semi-arid Africa. Field Crops Research, 132(14), 168-174.

Tomich, T. P., Lidder, P., Coley, M., Gollin, D., Meinzen-Dick, R., Webb, P., \& Carberry, P. (2018). Food and agricultural innovation pathways for prosperity. Agricultural Systems. https://doi.org/10.1016/j.agsy. 2018.01.002.

Uckert, G., Hoffmann, H., Graef, F., Grundmann, P., \& Sieber, S. (2015). Increase without spatial extension: Productivity in small-scale palm oil production in Africa - the case of Kigoma, Tanzania. Regional Environmental Change, 15(7), $1229-1241$.

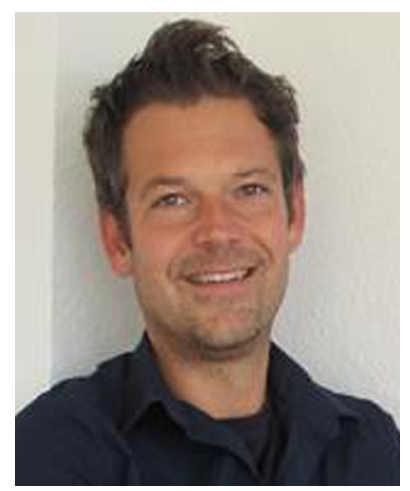

Stefan Sieber is an agricultural economist working as a senior scientist and head of the department "Sustainable Land Use in Developing Countries" at the Lebniz Centre for Agricultural Landscape Research (ZALF). As Associate Professor (German title: Privatdozent), he holds a $\mathrm{PhD}$ in agricultural sciences from the University of Bonn and finished his second degree $\mathrm{PhD}$ (Habilitation) at Humboldt Universität zu Berlin. He has extensive experience in agricultural sector modelling, particularly in terms of impact assessment of environmental and sustainability policies, as well as in applied monitoring and evaluation methods of international development projects worldwide (Europe, Latin America and Africa). Stefan Sieber has managed more than 30 research projects and has authored or co-authored more than 80 peer-reviewed publications, 12 peer-reviewed contributions for books and research series, as well as 80 conference papers. He is chair of the working commitee "International Research" of the Leibniz Association and is a lecturer for the "Environmental Sociology and Environmental Policy" Master's program at Humboldt Universität-Berlin. 


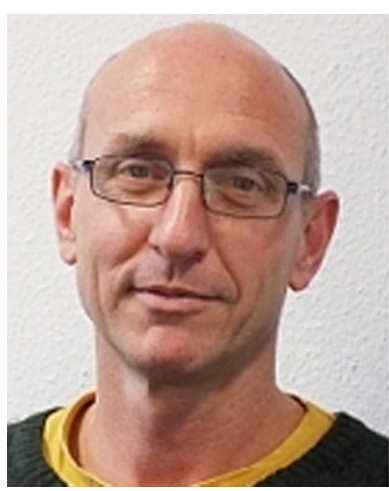

Frieder Graef works at the Lebniz Centre for Agricultural Landscape Research (ZALF) in Müncheberg, Germany. He holds a $\mathrm{PhD}$ in tropical agriculture from the University of Hohenheim, Germany, and has specialised in soil science, GIS, and land evaluation. Frieder is scientific coordinator of the German-Tanzanian research project, Trans-SEC. This stakeholder-driven project aims at improving food security for the vulnerable rural poor population in Tanzania, applying upgrading strategies along local and regional food value chains. Previously he worked at the Federal Agency of Nature Conservation $(\mathrm{BfN})$ in Bonn, Germany, where he was involved in the regulation of genetically modified organisms (GMO). There his special focus was on cultivation systems and strategies for monitoring their potential effects on biodiversity and ecosystems.

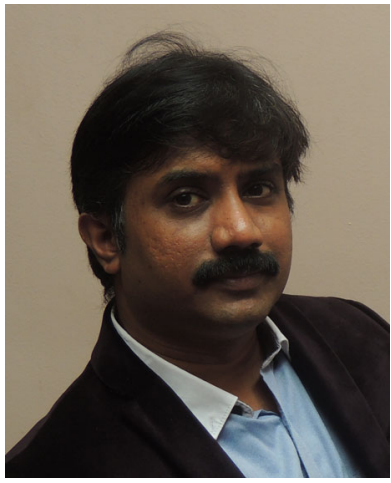

T. S. Amjath-Babu is a senior economist and guest researcher at the Leibniz Centre for Agricultural Landscape Research (ZALF), holding a doctorate from Justus Liebig University, Giessen. He has also worked as a consultant for CCAFS and ICIMOD. His focus is on the topics of water resource economics, climate change impact assessment, food security, and land use policy in Europe, Asia and Africa. Dr. Babu has authored around 25 international journal publications and managed multiple projects. He has extensive experience in mathematical modelling, statistical analysis, and indicator based assessments.

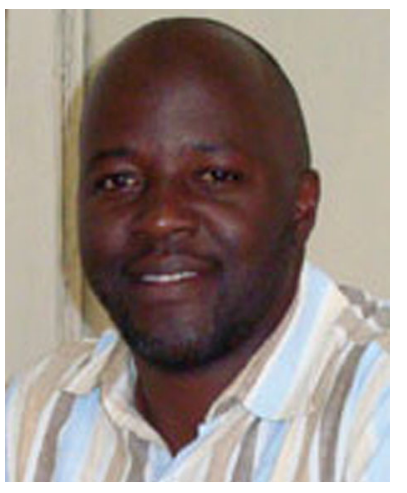

Khamaldin Daud Mutabazi is a senior lecturer at Sokoine University of Agriculture within the Department of Agricultural Economics and Agribusiness, Tanzania. He teaches undergraduate and postgraduate courses including mathematics for economists, econometrics, micro-economics, as well as research methods, planning and management. His areas of research, development and outreach, and consultancy include livelihoods analysis, the upgrading of agricultural value chains, agricultural marketing, smallholder commercialization and rural agribusiness development, the economics of climate change (micro-level adaptation and mitigation), as well as the implications of large-scale land-based investments on smallholder agriculture and rural development.

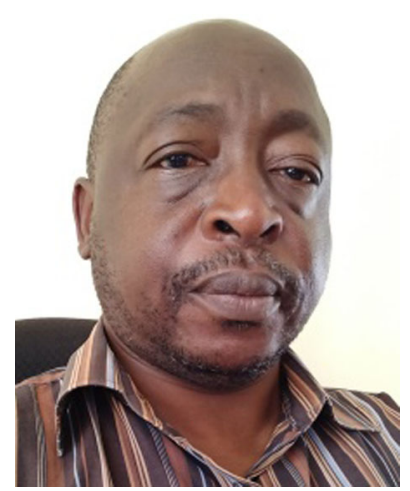

Siza Donald Tumbo is a Professor in Agricultural Engineering at Sokoine University of Agriculture and Director General for the Centre for Agricultural Mechanization and Rural Technology (CAMARTEC), Arusha, Tanzania. Areas of specialization include agricultural systems analysis and modeling, climate change, agricultural machinery and rural energy technologies, precision farming and automation of agricultural machinery.

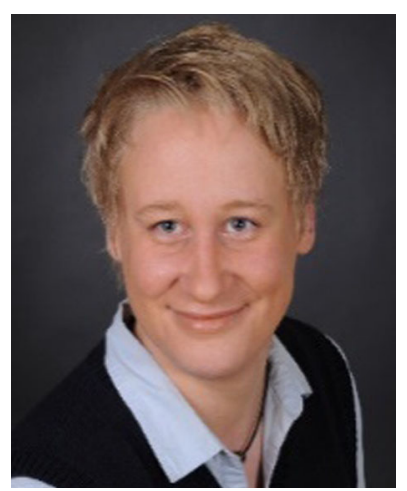

Anja Faße $(\mathrm{PhD})$ is Professor at the TUM Campus Straubing of Biotechnology and Sustainability for the Weihenstephan-Triesdorf University of Applied Sciences, Germany. She holds a PhD in economics specialising in environmental economics. Her research is on environmental value chain analysis and impact assessment on household welfare in developing countries especially in SubSaharan Africa. At the moment, she focuses on multiple innovation implementations in traditional rural value chains and their impact on poverty and food security in rural and urban areas.

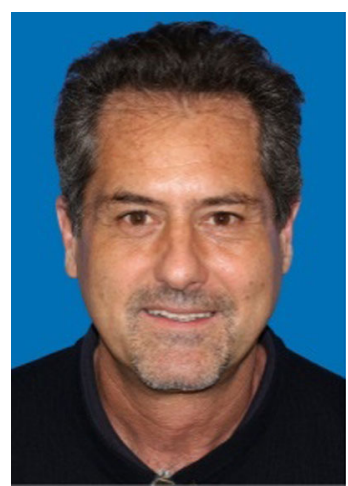

Sergio Gomez y Paloma is a senior researcher and scientific officer at the Joint Research Centre (JRC), European Commission (EC), Sevilla. He holds a degree in Agricultural sciences (Napoli University), a Master's degree in Agribusiness (Milano Catholic U.), a Master's degree in Agricultural systems analysis (Agro-Paris Tech), and a $\mathrm{PhD}$ in Agricultural economics (Bologna $\mathrm{U})$. Before joining the $\mathrm{EC}$ he was a Lecturer Development (Agro)Economics at Roskilde University. His main research interests include agricultural policy and production economics. He is currently leader for farm/regional level analysis at the JRC Unit for Economics of Agriculture, engaging in the area of food security policy impact analyses via FSSIM-DEV and IFM-CAP models (EU, Sub-Sahara Africa and Euro-Asia). He was, during 20112014, Member of the Editorial Board for the Applied Economics Perspective and Policy journal (Oxford University Press) and, during 2015-2017, Associate Editor of agricultural economics at the Journal of the International Association of Agricultural Economists (IAAE), Blackwell/Elsevier. 


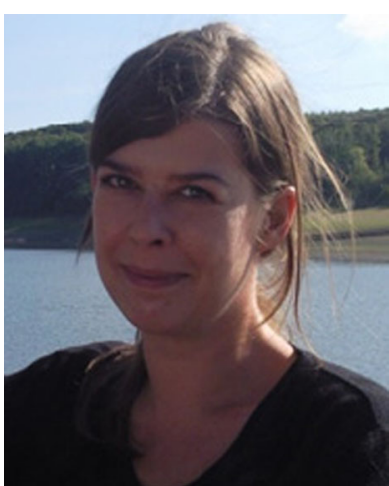

Constance Rybak $(\mathrm{PhD})$ is a nutritionist working at the Lebniz Centre for Agricultural Landscape Research (ZALF) and holds a PhD in nutritional science from ETH Zurich. Her research focuses on nutritional aspects in food security research. Further, her emphasis is to develop sustainable strategies that improve people's nutritional status with nutrition-sensitive and diversified agriculture. Since 2012 she has been working at ZALF and coordinates food security projects in Tanzania. Constance Rybak previously worked at Agroscope (Switzerland) and ETH Zurich.

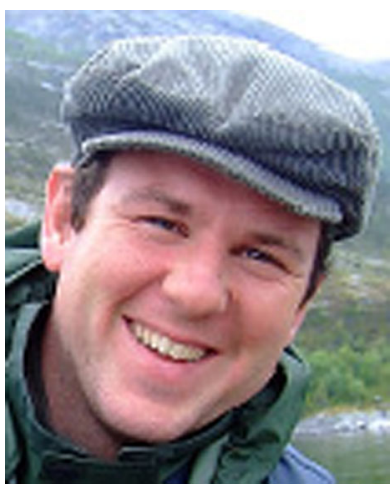

Marcos Alberto Lana holds a degree in Agronomy and a Master's in Agro-ecosystems from the Federal University of Santa Catarina State, Brazil. He holds a Doctoral degree in Crop Production from ChristianAlbrechts-Universität zu Kiel (CAU), Germany. Currently Marcos works as scientist and lecturer at the Swedish University of Agricultural Sciences in Uppsala, and as a visiting scientist at the Lebniz Centre for Agricultural Landscape Research (ZALF). His work is focused on the use of crop models to assess the impact of climate change on crops, and precision farming, so as to propose suitable adaptation strategies for the rural sector. Marcos is also involved with the development and adoption of agroecology as a tool to support sustainable farming systems. He is active across Europe, Africa, and Latin America. $\mathrm{He}$ also teaches at the Humboldt Universität zu Berlin, advising Bachelor's, Master's and $\mathrm{PhD}$ students.

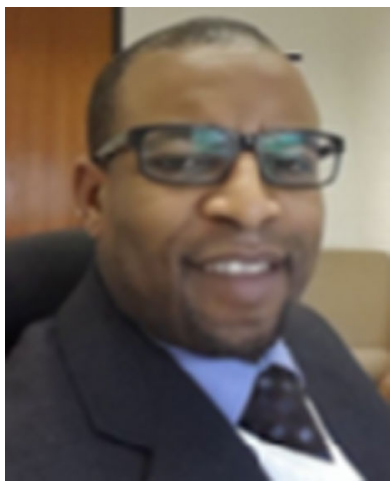

Hycenth Tim Ndah holds a PhD degree in Agricultural Sciences from Humboldt Universität zu Berlin and an MSc degree in Agricultural Sciences, Food Security, and Natural Research Management from the University of Hohenheim (DE). His research is focused on i) knowledge and innovation management; ii) adoption and diffusion processes of innovations; iii) participatory action research approaches; iv) innovation systems thinking in agriculture; and v) multi-stakeholder joint learning processes. Since 2008, he has been working with the Lebniz Centre for Agricultural Landscape Research (ZALF) and, in addition, he joined the University of Hohenheim in 2012 as a Research Associate and lecturer. He is actively involved in a range of innovation projects across Africa and Europe (e.g. CA2Africa, PRO AKIS, INCAA, AgriSPIN, amongst others) and has authored and co-authored, a number of peer reviewed publications around innovation studies.

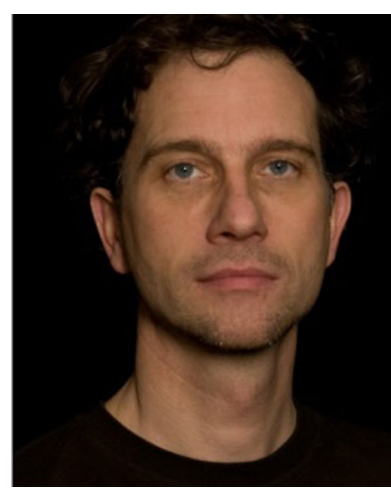

Götz Uckert is a scientist at the Lebniz Centre for Agricultural Landscape Research (ZALF), Germany, holding a $\mathrm{PhD}$ in plant nutrition and soil science from Christian-Albrechts-Universität zu Kiel (CAU) and an MBA from the University of Wales. He specializes in the implementation of renewable energy production in agriculture and local value chains, emphasising ecology and climate mitigation aspects and the socioeconomics of rural development. He has managed national and international research projects covering bioenergy, natural conservation, and climate change adaptation aspects of land use change. His current research focuses on food security, sustainable development, and impact assessment related to land use and sustainability options for renewable energy.

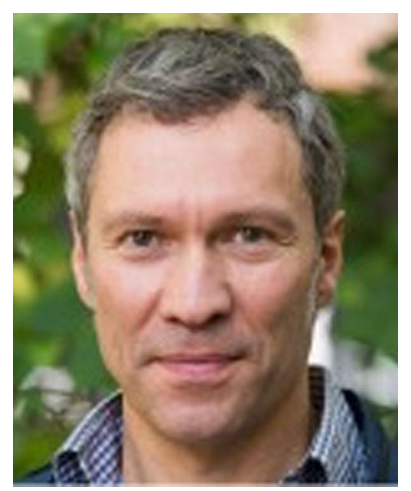

Dr. Johannes Schuler is a senior researcher in agricultural economics at the Lebniz Centre for Agricultural Landscape Research (ZALF). He has experience in a number of interdisciplinary projects on sustainable land use systems and expertise in the modelling of economic and environmental effects of land use on farm and regional scales, with a special focus on soil conservation. He has been involved in European projects such as the SoCo project (http://soco.jrc.ec.europa.eu), LUPIS, and CA2Africa. In CA2Africa he led the work package "Review and testing of model based tools for assessment of CA." He is currently the coordinator of the ERAFRICA project INCAA and works in the FACCEJPI project Climate-CAFÉ. He regularly teaches agricultural policy at the University of Applied Sciences Eberswalde and the University of Rostock.

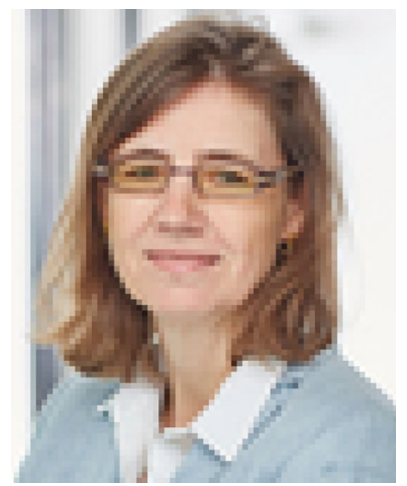

Ulrike Grote has been professor at the School of Economics and Management of the Leibniz University Hannover since 2006, where she heads the Institute for Environmental Economics and World Trade. Her research focuses both on environmental and development economics as well as on international trade. She has published widely on social and environmental standards, value chain analysis, and food security in the fields of agricultural and trade economics. She received her postgraduate degrees in Agricultural Economics from ChristianAlbrechts-Universität zu Kiel (CAU) and Bonn University, and is Senior Fellow at the Centre for Development Research (ZEF) in Bonn. Previously she worked for several years at international organizations such as the Asian Development Bank in Manila and the OECD in Paris. 